\title{
Determination of ethyl para methoxycinnamate content and anti-inflammatory test of Kaempferia galangal, L rhizome extract by inhibition of protein denaturation method
}

\author{
Laela Hayu Nurani", Aris Asahi, Hari Susanti \\ Postgraduate Pharmacy Study Program, Faculty of Pharmacy, Universitas Ahmad Dahlan \\ Jl. Prof. Dr. Soepomo, Janturan, Yogyakarta, Indonesia
}

Submitted: 29-04-2020

Reviewed: 12-07-2020

Accepted: 06-11-2020

\begin{abstract}
Kencur (Kempferia galanga, L) is one of the rhizomes that is often used as a constituent component in traditional medicinal formulas. One of the kencur's pharmacological activities is antiinflammatory. The active compound as an anti-inflammatory is ethyl p-methoxycinnamate (EPMC). This study aims to determine the content and ascertainment of EPMC compounds and the antiinflammatory activity of kencur rhizome extract. Kencur extract can be obtained by the maceration method using 96\% ethanol solvent. The EPMC content determination was held using the TLCdensitometry method, while the EPMC compounds were confirmed using the GC MS method. The anti-inflammatory activity test was done using inhibiting protein denaturation methods. The extract results obtained $12.67 \%$ yield. The result of EPMC content in kencur extract was $10.05 \pm 4.57$. The GCMS kencur extract results showed an abundance of EPMC compounds at a retention time of 7.088 with a peak area of 72290779 . The results of $\mathrm{IC}_{50}$ anti-inflammatory for the standard substance (EPMC) were $5.306 \pm 5.028$. The results of $\mathrm{IC}_{50}$ anti-inflammatory the sample (kencur extract) was $303.487 \pm 1.201$. Ethanol extract of kencur contains ethyl p-methoxycinnamate (EPMC) and has antiinflammatory activity by inhibiting protein denaturation.
\end{abstract}

Keywords: kencur extract, EPMC, determination of content, inhibition of protein denaturation

*Corresponding author:

Laela Hayu Nurani

Postgraduate Pharmacy Study Program, Faculty of Pharmacy

Universitas Ahmad Dahlan, Indonesia

J1. Prof. Dr. Soepomo, Janturan, Yogyakarta, Indonesia

Email: laela.farmasi@pharm.uad.ac.id 


\section{INTRODUCTION}

Indonesia is one of the countries with the largest tropical forests globally and has various traditional medicinal plants. One of the plants used for traditional medicine is kencur. Kencur is one of the commodities that has the biggest contribution to the total production of biopharma plants in Indonesia. The utilization of kencur reached 6.33\%. Kencur's total production in 2014 was 37.7 million kilograms (BPPP, 2017).

One of them is the pharmacological activity of kencur is anti-inflammatory (Samodra and Dina., 2020). Ethyl p-methoxycinnamate (EPMC) compounds are thought to play an active role as an antiinflammatory (Umar et al., 2014). The content of EPMC in kencur is $80.05 \%$ (Umar et al., 2012). Hudha et al. (2015) reported that EPMC compounds could be extracted by the maceration method using 96\% ethanol solvent. (Komala et al., 2017) reported that EPMC has anti-inflammatory activity with a pathway inhibition of protein denaturation.

Denaturation of proteins in tissues is a cause of inflammation (In et al., 2016), especially in conditions of arthritis. Protein denaturation is a state of loss of protein's structure and function through several triggers such as temperature, $\mathrm{pH}$, pressure, electricity, a mixture of chemicals, and reducing genes (Farida et al., 2018). The inhibition mechanism of protein denaturation is related to arachidonic acid metabolites as they are protein biomolecules (Umar et al., 2012).

The ester function groups in EPMC compounds contribute to anti-inflammatory activity. Komala et al. (2018) reported that the more $\mathrm{C}$ atoms in the ester group, the better the small concentration. EPMC, as an anti-inflammatory drug, has the same effect as a non-steroidal antiinflammatory drug (NSAID)(Syahruddin et al., 2017).

Its mechanism of action is on arachidonic acid metabolism, with decreased prostaglandin (PG) synthesis. This prostaglandin is an inflammatory mediator (Riasari et al., 2019) . Besides inhibiting PG synthesis, EPMC also inhibits several inflammatory mediators such as TNF- $\alpha$, IL1 $\beta$, and Nitric Oxide (NO), cytochrome P450 and CYP2E1 (Sirisangtragul and Sripanidkulchai.,2011; Umar et al., 2014). Therefore, inhibition of protein denaturation causes COX synthesis not to occur, thereby reducing inflammatory symptoms such as osteoarthritis (OA) (Umar et al., 2012; Komala et al., 2017). Based on the foregoing, the researcher wants to test EPMC and kencur extract's anti-inflammatory activity by inhibiting the protein denaturation method.

\section{MATERIALS AND METHOD Materials}

Materials used during the study included kencur rhizome, ethanol p.a. (Merck KGaA), methanol p.a. (Merck KGaA), ethyl acetate p.a. (Merck KGaA), Silica Gel $60 \mathrm{~F}_{254}$ (Merck KGaA), ethyl pmethoxycinnamate (Santa Cruz Biotechnology), $\mathrm{NaCl}$ (Merck KGaA), Tris Base (Merck KGaA), Albumin fraction V (Merck KGaA), Aquadest (Bratachem).

\section{Methods}

\section{Determination of Kaempferia galanga}

Determination of Kampferia galanga was carried out in the Biology Laboratory, Faculty of Applied Science and Technology, Ahmad Dahlan University, Yogyakarta.

\section{Preparation of kencur rhizome extract}

Kencur rhizome extract was made by the maceration method using $96 \%$ ethanol solvent. A total of 250 grams of kencur powder was put into a container made of glass, then $96 \mathrm{~mL}$ of ethanol was added much as $750 \mathrm{~mL}$ and stirred with a stirring machine for 3 hours. It was allowed to stand for 24 hours, then filtered with a vacuum pump, and the first macerate was obtained. Furthermore, the waste from the rest of the maceration process was re-macerated twice with the same treatment. The remaceration process aims to obtain optimal results on the powder performed by the sealing. Maceration results were then evaporated with a rotary evaporator at $\leq 50{ }^{\circ} \mathrm{C}$ until a thick liquid period was obtained. 
The evaporation results were evaporated above the water bath to form a thick extract period (Hudha et al., 2015 ; Kochuthressia et al., 2012).

\section{Qualitative test of EPMC compounds in samples (kencur extract) \\ Thin Layer Chromatography Test (TLC)}

Sample solutions (kencur extract) were prepared by dissolving $151.5 \mathrm{mg}$ in ethanol p.a. until dissolved, then were filtered and put in $10 \mathrm{~mL}$ measuring flask, then the ethanol p.a. was added to the limit of the flask.

Standard solution (ethyl p-methoxycinnamate) was prepared by dissolving $20 \mathrm{mg}$ in ethanol p.a. until dissolved. It was then filtered and put in a $10 \mathrm{~mL}$ flask, then ethanol p.a. was added to the flask's limit.

The stationary phase used is Silica Gel $60 \mathrm{~F}_{254}$ with plate size $(10 \times 20 \mathrm{~cm})$. Silica Gel $60 \mathrm{~F}_{254}$ is activated in an oven at $100^{\circ} \mathrm{C}$ for 30 minutes. The mobile phase used 2 types of solvents, namely ethyl acetate and methanol $(9: 1)$, then was saturated in the chamber. The standard solution was tested with 5 points tests: the samples were taken as many as 5 points on the plate and eluted to the limit. The Rf value was calculated from the elution result by comparing the length of the spotting distance and the elution limit.

\section{GCMS method}

Preparation of standard substance solution (EPMC) began with weighing as much as $50 \mathrm{mg}$ was in a flask with ethanol p.a. to $10 \mathrm{ml}$ flask. Preparation of sample solution (kencur extract), weighed as much as $200 \mathrm{mg}$ was in a flask with ethanol p.a. to $10 \mathrm{ml}$ flask, then filtered and a $5 \mathrm{mg} / \mathrm{mL}$ concentration was made.

Observation of the EPMC compound in the extract of the rhizome was done using GC-MS in the following conditions: Capillary Column HP-5MS $(30 \mathrm{~m} \times 0.25 \mathrm{~mm} \mathrm{ID} \times 0.25 \mu \mathrm{m}$ thickness of film). The separation was run at temperature of $105^{\circ} \mathrm{C}$ for 2 minutes, then raised to $300^{\circ} \mathrm{C}$ at a speed of $20{ }^{\circ} \mathrm{C} /$ minute and held for 20 minutes, Heater Transfer line MSD, The default gas is helium at a flow rate of $0.7 \mathrm{~mL} / \mathrm{min}$, Split ratio 100 , solution $1 \mu \mathrm{L}$ (concentration $5 \mathrm{mg} / \mathrm{mL}$ ) injected automatically, low mass scanning parameters 35 and a higher mass of 550.

\section{Quantitative test of EPMC compounds in samples (kencur extract)}

The result of thin-layer chromatography (TLC) containing standard substance spots and samples on a plate was then read on the TLC-Scanner Densitometer to determine the AUC (area under the curve) and the maximum absorption wavelength. The formula for calculating the was is as follows :

$$
\%=A s(1) \times C p(2) \times f \times 100
$$

Keterangan :

$$
\text { As (2) } \mathrm{Cu}(1)
$$

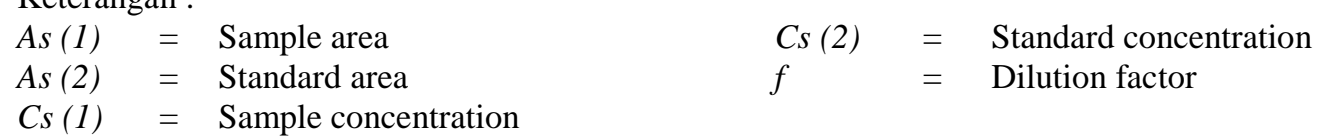

Protein denaturation inhibition assay

Anti-inflammatory activity assay was carried out using the method of inhibiting protein denaturation (Chandra et al., 2012).

\section{Preparation for tris buffer saline (TBS)}

As much as $4.35 \mathrm{~g}$ of $\mathrm{NaCl}$ was dissolved in $200 \mathrm{~mL}$ of aqua dest. $605 \mathrm{mg}$ of Tris Base was added and added to $400 \mathrm{~mL}$ of distilled water. Then the was is adjusted by adding glacial acetic acid to $\mathrm{pH}$ 6.3, Then added aqua dest up to $500 \mathrm{~mL}$. 


\section{Preparation of positive control solutions}

A total of $20 \mathrm{mg}$ of EPMC was dissolved in a $10 \mathrm{~mL}$ volumetric flask with sufficient ethanol p.a to a volume of $10 \mathrm{~mL}$ so that a concentration of $2000 \mu \mathrm{g} / \mathrm{ml}$ was obtained. The solution was made in 6 series: $3,3.5,4,4.5,5,5.5 \mu \mathrm{g} / \mathrm{mL}$, and a $0.1 \%$ BSA solution was added to the limit of the flask. Furthermore, it was incubated at $\pm 25^{\circ} \mathrm{C}$ for 30 minutes, then was heated in a closed water bath at $72^{\circ}$ $\mathrm{C}$ for 5 minutes and cooled at room temperature.

\section{Preparation of negative control solutions}

A total of $0.1 \mathrm{~g}$ of Bovine Serum Albumin (BSA) were added put into a $100 \mathrm{~mL}$ volumetric flask, then added with a TBS solution to a volume of $100 \mathrm{~mL}$. The solution was made in 6 series concentrations of distilled water: $3,3.5,4,4.5,5,5.5 \mu \mathrm{g} / \mathrm{mL}$, with a $0.1 \%$ BSA solution added to the flask's limit. Furthermore, it was incubated at $\pm 25^{\circ} \mathrm{C}$ for 30 minutes, then heated in a closed water bath at $72^{\circ} \mathrm{C}$ for 5 minutes and then at room temperature.

\section{Preparation of sample solutions}

A total of $100 \mathrm{mg}$ of extracts were dissolved in a $10 \mathrm{~mL}$ measuring flask with ethanol PA added up to $10 \mathrm{~mL}$ volume, so that a concentration namely $10,000 \mu \mathrm{g} / \mathrm{mL}$ was obtained. The next sample solution was made 6 series of concentrations of $150,200,250,300,350,400 \mu \mathrm{g} / \mathrm{mL}$, and $0.1 \%$ BSA solution were added to the limit of the measuring flask. Furthermore, it was then incubated at $\pm 25^{\circ} \mathrm{C}$ for 30 minutes, heated in a closed water bath at $72^{\circ} \mathrm{C}$ for 5 minutes and cooled at room temperature for 25 minutes.

\section{Absorbance measurement}

The measurement of the solution's absorbance was held using a UV-Vis spectrophotometer at a wavelength of $660 \mathrm{~nm}$.

Calculation of Percentage of Inhibition of Protein Denaturation.

The percentage of protein denaturation inhibition was measured using the following formula:

$$
\% \text { Inhibition }=(\text { Abs control negative-Abs Sample }) \times 100
$$

Abs control negative

\section{Data Analysis}

The percent inhibition data was tested partially using SPSS with a 95\% confidence level. The anti-inflammatory $\mathrm{IC}_{50}$ value was obtained by determining the linear regression between the percent inhibition (Y) and the concentration (X).

\section{RESULT AND DISCUSSION}

Determination of Kaempferia galanga

Kaempferia galanga's determination was carried out in the Biology Laboratory of the Faculty of Applied Science and Technology Ahmad Dahlan University. The results of determination show that the kencur rhizome plant used in this study was correct; the key of determination is as follows:

$1 b-2 b-3 b-4 b-12 b-13 b-14 b-17 b-18 b-19 b-20 b-21 b-22 b-23 b-$

$24 b-25 b-26 b-27 a-28 b-29 b-30 b-31 a-32 a-33 a-34 b-333 b-334 b-335 a-336 a-$ $337 b-338 a-339 b-340 a-$ Zingiberaceae

$1 \mathrm{a}-2 \mathrm{a}-3 \mathrm{~b}-4 \mathrm{a}-5 \mathrm{~b}$ Kaempferia

1a Kaempferia galangal $L$ 


\section{Qualitative test of EPMC in samples (kencur extract)}

Thin layer chromatography (TLC)

TLC sample test (kencur extract) were carried out in Silica Gel $60 \mathrm{~F}_{254}$ stationary phase. The mobile phase that used was the ratio between ethyl acetate and methanol (9:1). The appearance of thin layer chromatography under $\mathrm{UV}_{254}$ can be seen in Figure 1 with an Rf value of 0.75 .

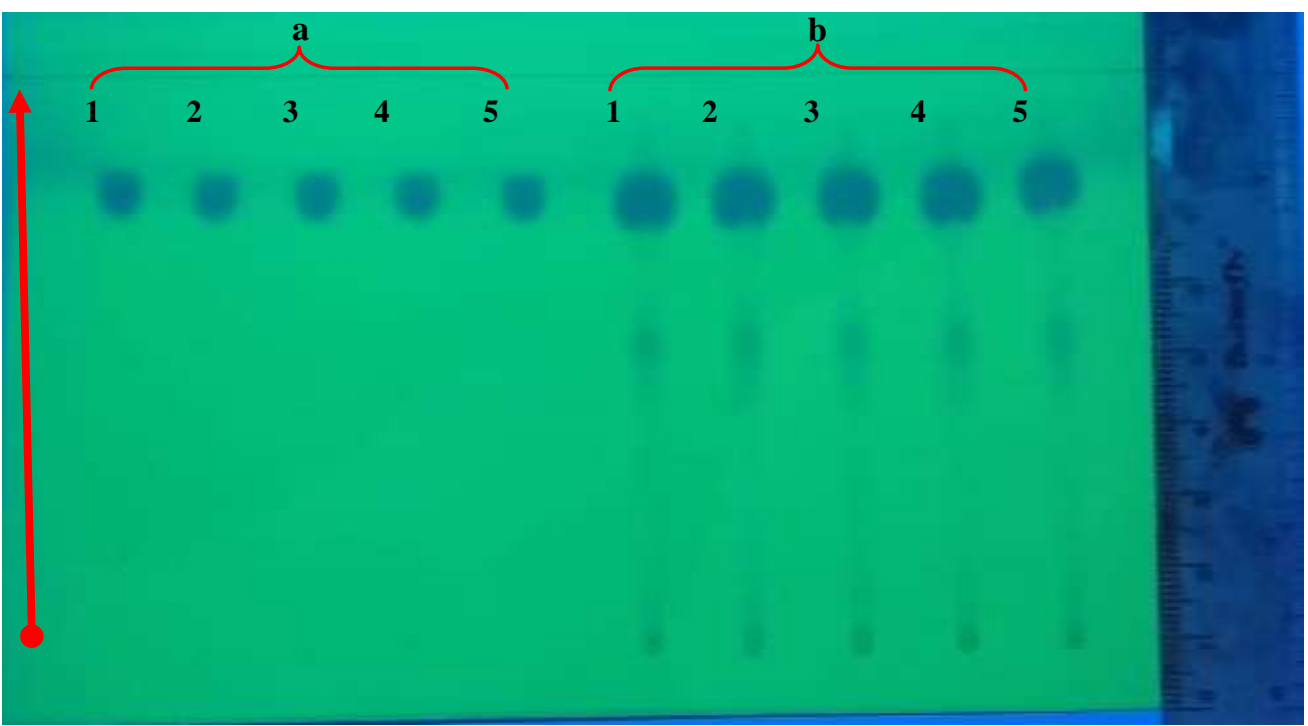

Figure 1. Thin layer chromatography results (a 1-5) EPMC (b 1-5) kencur extract, silent phase; silica gGel $60 \mathrm{~F}_{254}$, mobile phase; ethyl acetate and methanol (9: 1), detection; $\mathrm{UV}_{254}$, elution direction

\section{GCMS}

The observation of EPMC in kencur extract was carried out using the method of Gas Chromatography-Mass Spectrometry (GCMS) method. The standard chromatogram substance at 7.045 retention time was 112851970 , and kencur extract chromatogram abundant at 7.088 retention time was 72290779. The abundance of compounds based on retention times was presented in Table 1. Results of standard substance chromatograms Figure 2.

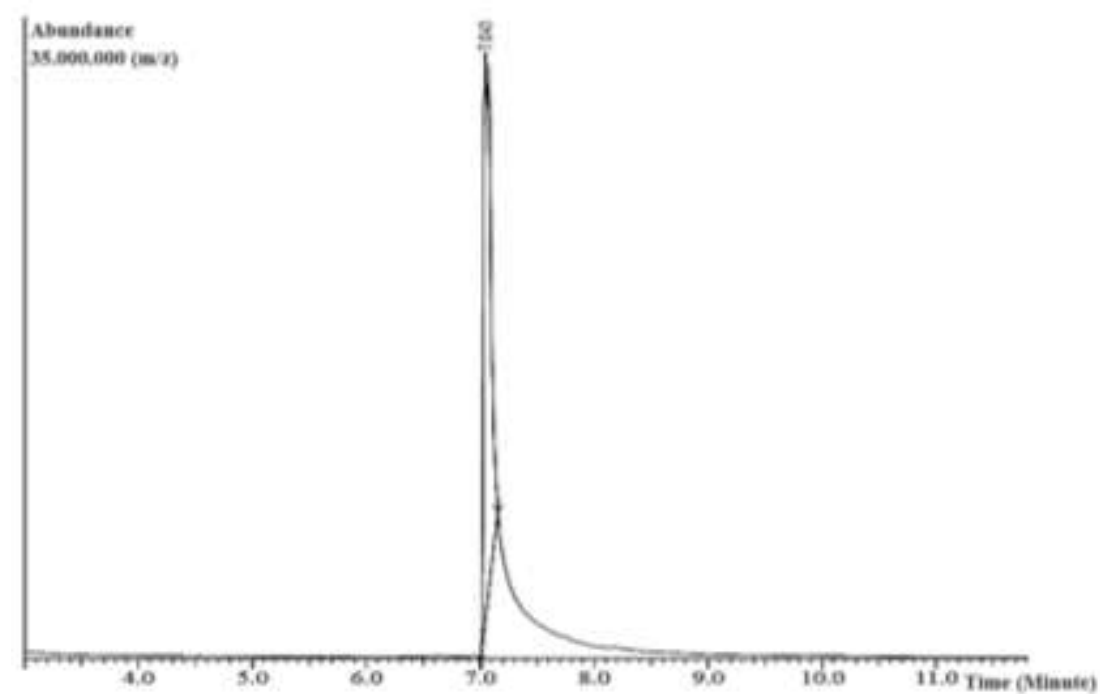

Figure 2. Standard substance chromatogram (EPMC)

Determination of ethyl ...(Nurani et al.,) 
Table 1. Abundance of compounds based on retention time

\begin{tabular}{ccc}
\hline Retention Time & Compound & Abundance \\
\hline 5.583 & Pentadecan & 10551694 \\
6.207 & Pentadecan & 110952 \\
6.614 & Oktadecan & 2343457 \\
6.691 & 2-Propenoic acid & 1909661 \\
6.872 & Limonene oxide & 1895806 \\
$\mathbf{7 . 0 8 8}$ & Ethyl p-methoxycinnamate & $\mathbf{7 2 2 9 0 7 7 9}$ \\
8.161 & Hexadecanoic acid & 5465394 \\
9.773 & 9-Oktadecenoic acid & 1535728 \\
\hline
\end{tabular}

\section{Quantitative Test of EPMC compounds in samples (Kencur Extract)}

Maximum absorption wavelength screening from kencur extract was $307 \pm 0.46$ and EPMC 308 \pm 0.32 . TLC results were screened on a TLC-Scanner densitometer tool to determine the peak area of each spot. Area under curve (AUC) values for Figure 1 were presented in Table 2. The result of the calculation of the average content was $10.05 \pm 4.57$. Indonesian herbal pharmacopeia guidelines state that the minimum value in determining EPMC levels by the TLC-Densitometry method was not less than $4.30 \%$, meaning that the test was appropriate.

Table 2. AUC Values of standard substances (EPMC) and AUC samples (Kencur extract)

\begin{tabular}{ccc}
\hline AUC Standard & AUC Sample & \% Content \\
\hline 106007.1 & 82101.9 & 10.44 \\
100510.2 & 82713.8 & 10.51 \\
104032.3 & 78582.3 & 9.99 \\
104930.7 & 78192.5 & 9.94 \\
103798.0 & 73712.7 & 9.37 \\
\hline Information : Concentration Standard $: 2 \mathrm{mg} / \mathrm{mL} ;$ Concentration Sample $: 15.15 \mathrm{mg} / \mathrm{mL}$
\end{tabular}

\section{Inhibition of protein denaturation}

The anti-inflammatory activity test with protein denaturation inhibition was carried out with Bovine Serum Albumin (BSA) $0.1 \%$. BSA as a negative control denatured due to heating in in-vitro testing. The standard substance (EPMC) is a positive control that inhibits denatured BSA, while the inhibition by kencur rhizome extract in a variety of concentrations will then be observed. If the inhibitory percentage result $>20 \%$, it was considered to have anti-inflammatory potential (Farida et al., 2018). The results of percent inhibition by EPMC and kencur extract were presented in Figure 3.

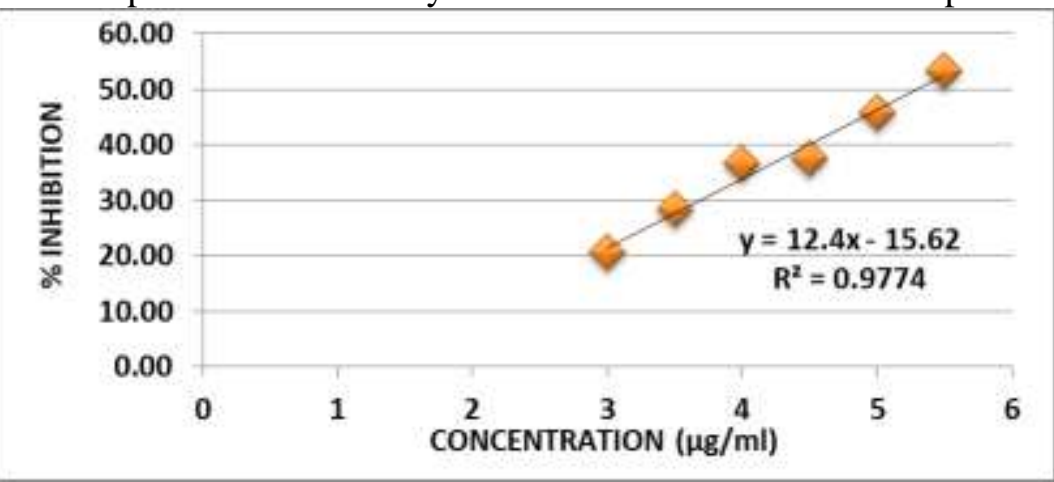

Figure 3. Percent inhibition of protein denaturation by EPMC 


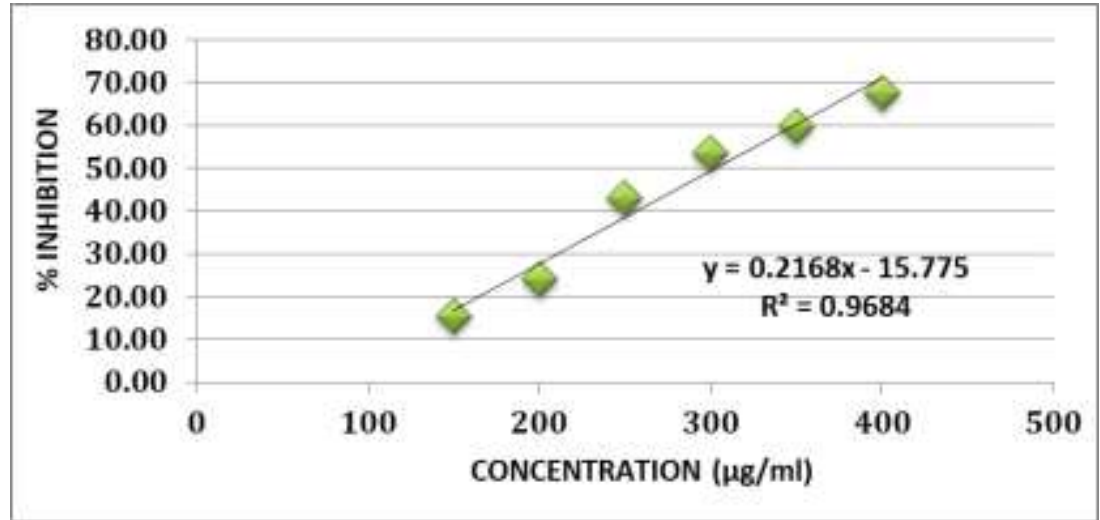

Figure 4. Percent inhibition of protein denaturation by kencur extract

Figure 3 and Figure 4 shows the average of denaturation inhibition. The increased inhibition of protein denaturation accompanied increased concentration. It means kencur extract has the same potential as ethyl para methoxycinnamate in inhibiting protein denaturation. Determination of $\mathrm{IC}_{50}$ value of standard anti-inflammatory substance (EPMC) and samples (kencur extract) in inhibiting protein denaturation began with determining a linear regression between concentration (X) and percentage of inhibition (Y). $\mathrm{IC}_{50}$ values of standard anti-inflammatory substances (EPMC) were presented in Table 3, and samples (kencur extract) were presented in Table 4.

Table 3. IC $_{50}$ Anti-inflammation standard substance (Ethyl Para Methoxy Cinnamate)

\begin{tabular}{cccccc}
\hline \multirow{2}{*}{$\begin{array}{c}\text { Concentration } \\
(\boldsymbol{\mu g} / \mathbf{m l})\end{array}$} & \multicolumn{5}{c}{ \% Inhibition Of Protrein Denaturation } \\
\cline { 2 - 6 } & $\begin{array}{c}\text { Replication } \\
\mathbf{1}\end{array}$ & $\begin{array}{c}\text { Replication } \\
\mathbf{2}\end{array}$ & $\begin{array}{c}\text { Replication } \\
\mathbf{3}\end{array}$ & $\begin{array}{c}\text { Replication } \\
\mathbf{4}\end{array}$ & $\begin{array}{c}\text { Replication } \\
\mathbf{5}\end{array}$ \\
\hline 3 & 24.261 & 19.581 & 20.074 & 19.581 & 20.197 \\
3.5 & 29.461 & 33.174 & 30.299 & 24.192 & 24.311 \\
4 & 38.056 & 36.300 & 42.740 & 33.021 & 32.904 \\
4.5 & 41.829 & 40.229 & 32.686 & 36.229 & 36.800 \\
5 & 46.416 & 44.596 & 48.350 & 43.345 & 46.871 \\
5.5 & 56.285 & 53.504 & 61.290 & 47.497 & 48.276 \\
\hline
\end{tabular}

Table 4. IC $_{50}$ Anti-inflammation sample (Kencur Extract)

\% Inhibition Of Protein Denaturation

\begin{tabular}{|c|c|c|c|c|c|}
\hline $\begin{array}{c}\text { Concentration } \\
(\mu \mathrm{g} / \mathrm{ml})\end{array}$ & $\begin{array}{c}\text { Replication } \\
1\end{array}$ & $\begin{array}{c}\text { Replication } \\
\quad 2\end{array}$ & $\begin{array}{c}\text { Replication } \\
\mathbf{3}\end{array}$ & $\begin{array}{c}\text { Replication } \\
4\end{array}$ & $\begin{array}{c}\text { Replication } \\
5\end{array}$ \\
\hline 150 & 15.079 & 15.079 & 15.193 & 15.420 & 15.420 \\
\hline 200 & 23.208 & 25.939 & 22.753 & 25.028 & 22.753 \\
\hline 250 & 41.133 & 43227 & 45.074 & 44.335 & 41.379 \\
\hline 300 & 52.798 & 55.961 & 51.582 & 53.771 & 53.528 \\
\hline 350 & 61.758 & 60.689 & 59.501 & 56.651 & 60.570 \\
\hline 400 & 65.192 & 66.589 & 67.520 & 72759 & 65.308 \\
\hline
\end{tabular}

The percent denaturation of protein inhibition was tested using Statistic Product and Service Solutions (SPSS) with a 95\% confidence level. T-test results on standard substances (EPMC) showed that the value of $\mathrm{T}$ Count $>\mathrm{T}$ Table $(14.964>2.13185)$; it was concluded that the increase in 
concentration had a significant effect on the percent inhibition. T-test results on the sample (kencur extract) showed the value of T Count $>\mathrm{T}$ Table $(26.165>2.13185)$; it was concluded that the increase in concentration had a significant effect on the percent inhibition.

Komala et al. (2018) reported that isolates (EPMC) at a $100 \mu \mathrm{g} / \mathrm{mL}$ concentration could inhibit $51.6 \pm 1.2$. In this study, kencur extract showed a non-strong anti-inflammatory potential at a concentration of $303.487 \pm 1.201$, because the EPMC content of the isolated product was greater. Based on this, the sample (kencur extract) has the potential to inhibit protein denaturation $\pm 32.95 \%$. The standard substance (EPMC) shows a strong anti-inflammatory potential at a concentration of $5.306 \pm 5.028$, due to the pure substance (EPMC) used in the test.

The mechanism of inhibition of protein denaturation by the EPMC compound is closely related to the inhibition of arachidonic acid metabolites. Arachidonic acid is a biomolecule in proteins, such as cyclooxygenase and lipoxygenase, that cause inflammation. Umar et al. (2012) reported that EPMC has a mechanism to inhibit COX1 and COX2. In the treatment of inflammation with kencur extract in the medical world, it was reported that kencur extract has the same effect as one of the non-steroidal anti-inflammatory drugs (NSAIDs) namely meloxicam (Ekowati et al., 2015 ; Syahruddin et al., 2017).

The functional groups of ethyl esters in EPMC compounds contribute the most to antiinflammatory activity. Komala et al. (2018) reported that the more $\mathrm{C}$ atoms in the ester group, the better the small concentration. The potential of EPMC as an anti-inflammatory drug is similar to meloxicam. Its action mechanism is to inhibit the enzyme cyclooxygenase (COX) in arachidonic acid metabolism, resulting in decreased prostaglandin (PG) synthesis arising from tissue injury. This prostaglandin is an inflammatory mediator that can cause tumors (swelling) and pain onset (dolor). Therefore, inhibiting COX synthesis can reduce inflammatory symptoms such as osteoarthritis (OA). In addition to inhibiting PG synthesis, EPMC also inhibits several inflammatory mediators TNF- $\alpha$, IL1 $\beta$, and Nitric Oxide (NO), cytochrome p450 and CYP2E1 (Ekowati et al., 2015 ; Sirisangtragul and Sripanidkulchai., 2011; Umar et al., 2014).

\section{CONCLUSION}

Ethanol extract of Kaempferia galanga has an EPMC content of $10.05 \pm 4.57$. The $\mathrm{IC}_{50}$ value of standard anti-inflammatory substances (EPMC) was $5.306 \pm 5.028$, and the $\mathrm{IC}_{50}$ value of the ethanol extract of kencur extract was $303.487 \pm 1.201$ by inhibition of protein denaturation mechanism.

\section{REFERENCES}

BPPP, 2017, Info Komoditi Tanaman Obat (E. Salim, Zamroni Munadi, ed.). Jakarta: Kementrian Perdagangan Republik Indonesia.

Chandra, S., Priyanka, C., Protapaditya, D., Sanjib, B., 2012, Evaluation of in vitro anti-inflammatory activity of coffee against the denaturation of protein, Asian Pacific Journal of Tropical Biomedicine, S178-S180.

Ekowati, J., Suko, H., and Iwan, S. H., 2015, Ethyl p-methoxycinnamate from Kaempferia galanga inhibits angiogenesis through tyrosine kinase, Universa Medicina, 34 (1) : 43-51

Farida, Y., Rahmat, D. and Amanda, A. W., 2018, Uji Aktivitas Antiinflamasi Nanopartikel Ekstrak Etanol Rimpang Temulawak (Curcuma xanthorrhiza Roxb.) dengan Metode Penghambatan Denaturasi Protein, Jurnal Ilmu Kefarmasian Indonesia, 16(2) : 225-230.

Hudha, M. I., Daryono, E. D. and Muyassaroh., 2015, Optimalisasi Proses Isolasi Etil Parametoksisinamat ( EPMS ) Dari Rimpang Kencur dengan Variasi Proses dan Konsentrasi Pelarut, Seminar Nasional Teknologi, 757-762.

In, M.H., Byoung. K. J., Yeun-Ja, M., Won-Hong, W., 2016, Hexane Extract of Kaempferia galanga L. Suppresses Melanogenesis via p38, JNK and Akt, J Physiol \& Pathol Korean Med, 30 (1) : 47-53.

Kochuthressia, K. P., S.John, B., Jaseentha, M.O., and Rini, R., 2012, In vitro antimicrobial evaluation of Kaempferia galanga L. rhizome extract, American Journal Biotechnology And Molecular Sciences, 2 (1): 1-5.

Komala, I., Supandi, Nurhasni, Betha, O. S., Putri, E. and Mufidah, S., 2018, Structure-activity relationship study on the ethyl p-methoxycinnamate as an anti-inflammatory agent, Indonesian 
Journal of Chemistry, 18(1): 60-65.

Komala, I., Supandi, Nurhasni, Betha, O. S., Yardi, and Mufidah, S., 2017, Microwave assisted synthesis of p-methoxycinnamides and p-methoxy- $\beta$-nitrostyrenes from ethyl pmethoxycinnamate and screening their anti-inflammatory activity, Natural Product Communications, 12(8) : 1265-1268.

Riasari, H., Revika, R., Sri, W., 2019, Evaluation Patch of Rhizoma Extract Kencur (Kaempferia galanga L.) as Anti-Inflammatory with Enhancer, Indonesian Journal of Pharmaceutical Science and Technology, 6 (2) : 59-64

Samodra, G., and Dian, F., 2020, Anti-Inflammatory Effects of Kaempferia galanga L. Rhizome Extract in Carrageenan-Induced Female Rats, Advances in Health Sciences Research, 20 : 13-17.

Sirisangtragul, W. and Sripanidkulchai, B., 2011, Effects of Kaempferia galanga L. and ethyl-p methoxycinnamate (EPMC) on hepatic microsomal cytochrome P450s enzyme activities in mice, Songklanakarin Journal of Science and Technology, 33(4) : 411-417.

Syahruddin, A. N., Dahlan, C. K.. and Taslim, N. A., 2017, The Effects of Kaempferia Galanga L . Extract on Pain, Stiffness and Functional Physic in Patient with Knee Osteoarthritis: Double Blind Randomized Clinical Trial, International Journal of Science and Healthcare Research, 2(4) : 37-43.

Umar, M. I., Asmawi, M. Z., Sadikun, A., Atangwho, I. J., Yam, M. F., Altaf, R. and Ahmed, A., 2012, Bioactivity-guided isolation of ethyl-p-methoxycinnamate, an anti-inflammatory constituent, from Kaempferia galanga L. extracts, Molecules, 17(7) : 8720-8734.

Umar, M. I., Asmawi, M. Z., Sadikun, A., Majid, A. M. S. A., Al-Suede, F. S. R., Hassan, L. E. A. and Ahamed, M. B. K. 2014., Ethyl-p-methoxycinnamate isolated from Kaempferia galanga inhibits inflammation by suppressing interleukin- 1 , tumor necrosis factor- $\alpha$, and angiogenesis by blocking endothelial functions, Clinics, 69(2) : 134-144. 
